\title{
Acute myocardial infarction in a young patient with hyperhomocysteinaemia
}

\author{
Vincent Ukachukwu, Salah Idris, Alister Mcllwee \\ Emergency Department, Ulster Hospital, Belfast, UK
}

Correspondence to Dr Salah Idris, salahidris2002@yahoo.co.uk

\begin{abstract}
Summary
Homocysteinuria is a rare inborn error of metabolism known to be associated with an increased risk of vascular events. A 36-year-old Caucasian man presented with a 2day history of epigastric discomfort associated with nausea and sweating. He has a history of homocysteinuria and had been poorly compliant with treatment. An ECG showed ST-segment elevation and 0-waves in anterior leads. Blood tests showed markedly elevated high-sensitivity troponin and high homocysteine levels. He had a failed primary percutaneous coronary intervention due to extensive thrombus in the left anterior descending artery, which was aspirated and he received integrelin infusion for $48 \mathrm{~h}$. Echocardiogram showed mild-to-moderate impairment of left ventricular function with apical akinesis extending to the mid-portion of anteroseptal walls consistent with anterior myocardial infarction. He was started on homocysteine-lowering treatment with betaine and folic acid. He is now on follow-up with clinical chemistry and cardiac rehabilitation.
\end{abstract}

\section{BACKGROUND}

Homocysteinuria is a rare inborn error of methionine metabolism that results in hyperhomocysteinaemia. In the classical form of the disease there is deficiency of an enzyme cystathione $\beta$-synthase, which converts homocysteine to cystathione in a reaction that uses vitamin $B_{6}$, vitamin $B_{12}$ and folic acid as cofactors. Hyperhomocysteinaemia has been recognised as an independent cardiovascular risk factor. ${ }^{1}{ }^{2}$ A landmark study by Mudd et $a l^{3}$ showed that individuals with homocysteinuria have a $50 \%$ chance of having a vascular event by age 30 years. The mainstay of management homocysteinuria is dietary restriction of methionine, as well as homocysteine-lowering treatment with pyridoxine $\left(\mathrm{B}_{6}\right)$, folic acid, vitamin $B_{12}$ and betaine. It has been shown that such treatment significantly reduces the risk of vascular events. ${ }^{4} 5$ This case highlights the importance of compliance with homocysteine-lowering treatment in patients with homocysteinuria and aims to raise awareness of this rare disease condition among clinicians. It also highlights the importance of evaluating atypical presentation of cardiac chest pain in young people without the typical cardiovascular risk factors.

\section{CASE PRESENTATION}

The patient is a 36-year-old gentleman who presented to the emergency department complaining of progressively worsening intermittent epigastric discomfort for 2 days, associated with sweating and nausea. He has a history of homocysteinura and was said to have been poorly compliant with his treatment in the last few years. He also has hypertension and asthma. His social history revealed moderate alcohol intake and no history of smoking or illicit drug use. He had no other risk factors for ischaemic heart disease. His pulse rate was 82 beats/min, blood pressure $168 / 102 \mathrm{~mm} \mathrm{Hg}$, respiratory rate 18 cycles/min and oxygen saturation $98 \%$ on room air. Systemic examination was unremarkable.

\section{INVESTIGATIONS}

An ECG (figure 1) showed an ST-segment elevation in leads V2-V6, with $\mathrm{Q}$-waves in anterior leads. Chest x-ray showed features of early pulmonary oedema. Initial highsensitivity troponin result was $927 \mathrm{ng} / \mathrm{l}(0-14 \mathrm{ng} / \mathrm{l})$ and total homocysteine was $187 \mu \mathrm{mol} / \mathrm{l}(5.5-13.6 \mu \mathrm{mol} / \mathrm{l})$, falling to $50 \mu \mathrm{mol} / \mathrm{l}$ on discharge. The patient's homocysteine levels had previously been in the range $20-30 \mu \mathrm{mol} / \mathrm{l}$. Total cholesterol was $4.8 \mathrm{mmol} / \mathrm{l}$, high-density lipoprotein (HDL) $1.5 \mathrm{mmol} / \mathrm{l}$, triglycerides $2.48 \mathrm{mmol} / \mathrm{l}$, cholesterol/ HDL ratio 3.20. Echocardiogram showed mild-to-moderate impairment of left ventricular systolic function with apical akinesis extending to the mid-portion of anteroseptal walls consistent with anterior myocardial infarction (MI).

\section{DIFFERENTIAL DIAGNOSIS}

Dyspepsia-this is a common differential diagnosis for epigastric pain in this age group but would be a dangerous diagnosis to make in this patient given his background history of hyperhomocysteinaemia.

Cocaine-induced MI-given the patient's age and risk profile, this must be considered as a possible differential diagnosis. However, he had no history of illicit drug use and a 2-day history of chest pain is not typical of MI from cocaine use. Furthermore, angiography confirmed the presence of thrombus in coronary vessels.

\section{TREATMENT}

Patient received high flow oxygen, aspirin $300 \mathrm{mg}$, clopidogrel $600 \mathrm{mg}, 4$ puffs of glyceryl trinitrate spray and diamorphine $5 \mathrm{mg}$. He was transferred to another facility for primary percutaneous coronary intervention (PCI). However, primary PCI failed due to a large clot in the left 


\section{BMJ Case Reports}

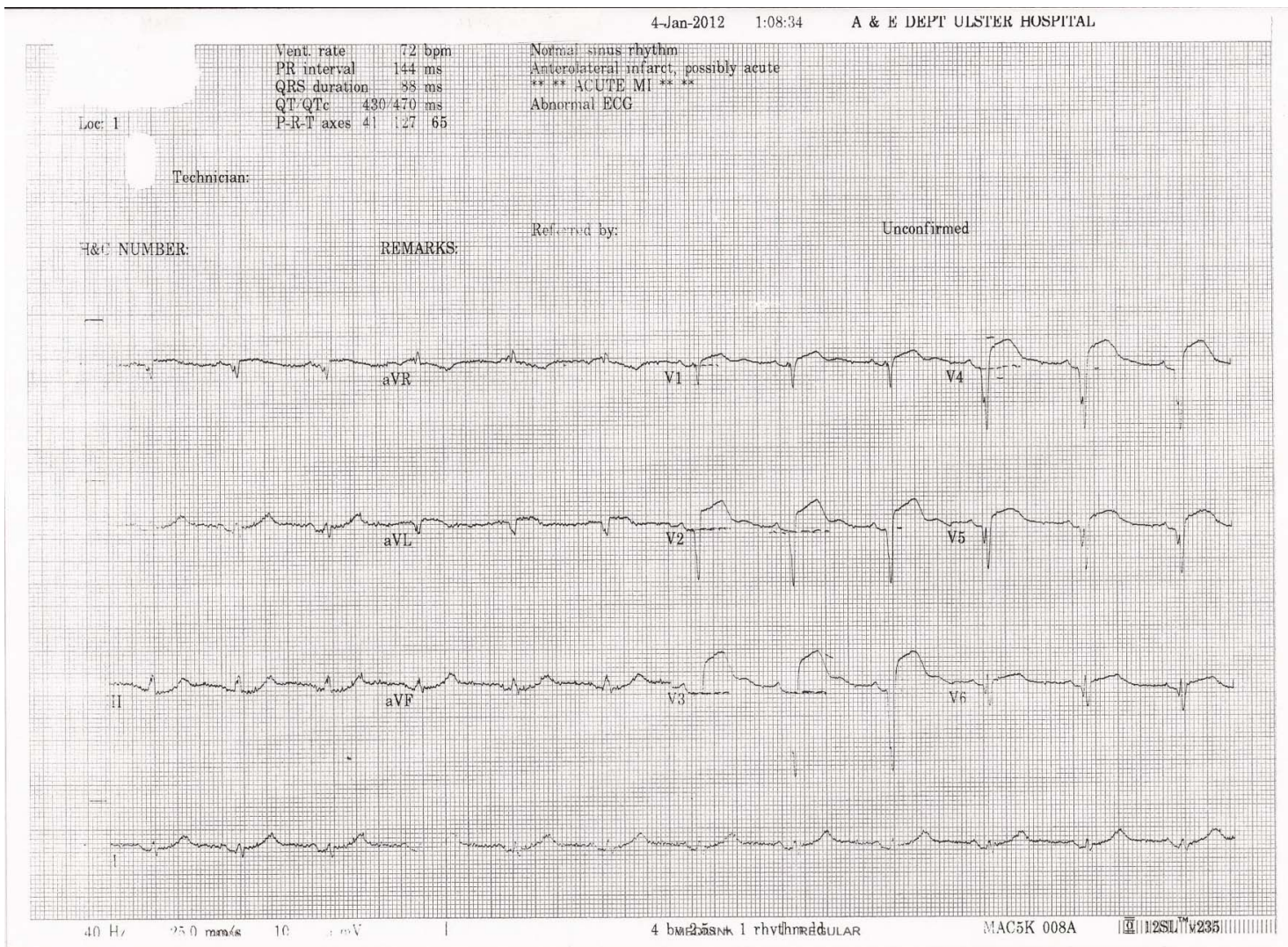

Figure 1 ECG showed an ST-segment elevation in leads V2-V6, with Q-waves in anterior leads.

anterior descending artery. The thrombus was aspirated and he was started on integrelin infusion for $48 \mathrm{~h}$ to help reduce the thrombus. The rest of the vessels were normal.

\section{OUTCOME AND FOLLOW-UP}

The patient made a good recovery. He was started on betaine and folic acid and was discharged home for outpatient follow-up with clinical chemistry and cardiac rehabilitation.

\section{DISCUSSION}

The patient is young and his presentation was atypical. In the absence of typical cardiovascular risk factors such as a family history of ischaemic heart disease, smoking and dyslipidaemia, such cases can easily be missed especially in the primary care setting or in the emergency department. This case highlights the importance of maintaining a high index of suspicion for cardiac chest pain even in young patients with atypical chest pain.

The case also underscores the benefits of homocysteinelowering treatment in homocystinuria as has been highlighted in various studies. ${ }^{4}$ It has been shown that even modest reductions in homocysteine levels are associated with significant reductions in risk of vascular events, including myocardial infarction. It remains unclear as to whether the protective effect of such treatment relates to the lower homocysteine levels or whether it is to do with some hitherto unknown vascular protective effect of the agents. ${ }^{6}$

The overwhelming evidence of benefit of homocysteinelowering treatment in homocysteinuria, as well as epidemiological evidence of possible benefit in the general population ${ }^{7}$ has led to suggestions of likely usefulness of homocysteine-lowering treatment in secondary prevention of stroke and myocardial infarction, but results of randomised controlled trials have been inconclusive ${ }^{89}$ and possibly harmful. ${ }^{10} 11$ However, for patients with homocysteinuria treatment could mean the difference between life and death or serious morbidity, and it is important that clinicians looking after these patients are aware of the increased cardiovascular and cerebrovascular risk.

\section{Learning points}

- Clinicians should be aware of the increased cardiovascular and cerebrovascular risk in patients with hyperhomocysteinaemia.

- Homocysteine-lowering treatment should be prescribed and adherence encouraged among patient with homocysteinuria.

- Clinicians should maintain a high index of suspicion for cardiac chest pain in patients with indigestion-type chest pain even in the young and in the absence of typical cardiovascular risk factors.

Competing interests None.

Patient consent Obtained. 


\section{REFERENCES}

1. The Homocysteine Studies Collaboration. Homocysteine and risk of ischemic heart disease and stroke: a meta-analysis. JAMA 2002:288:2015-22.

2. Arnesen $\mathbf{E}$, Refsum $\mathrm{H}$, Bonaa $\mathrm{KH}$, et al. Serum total homocysteine and coronary heart disease. Int J Epidemiol 1995;24:704-9.

3. Mudd SH, Skovby F, Levy HL, et al. The natural history of homocystinuria due to cystathionine-synthase deficiency. Am J Hum Genet 1985;37:1-31.

4. Wilcken DEL, Wilcken B. The natural history of vascular disease in homocystinuria and effects of treatment. J Inherited Metab Dis 1997;20:295-300.

5. Yap S, Naughten ER, Wilcken B, et al. Vascular complications of severe hyperhomocysteinemia in patients with homocystinuria due to cystathionine beta-synthase deficiency: effects of homocysteine lowering therapy. Semin Thromb Hemost 2000;26:335-40.

6. Yap S, Godfried H J Boers, Wilcken B, et al. Vascular outcome in patients with homocystinuria due to cystathionine b-synthase deficiency treated chronically: a Multicenter Observational Study. Arterioscler Thromb Vasc Biol 2001;21:2080-5

7. American Heart Association. Stroke deaths reduced by folic acid fortification: meeting report. 5 March 2004. http://scienceblog.com/ community/older/2004/1/2004533.shtml (accessed 14 Aug 2012).

8. Toole JF, Malinow MR, Chambless LE, et al. Lowering homocysteine in patients with ischemic stroke to prevent recurrent stroke, myocardial infarction, and death: the vitamin intervention for stroke prevention (VISP) randomized controlled trial. JAMA 2004;291:565-75.

9. Schnyder G, Roffi M, Pin R, et al. Decreased rate of coronary restenosis after lowering of plasma homocysteine levels. N Engl J Med 2001;345:1593-600.

10. Lange H, Suryapranata H, De Luca G, et al. Folate therapy and in-stent restenosis after coronary stenting. N Engl J Med 2004;350:2673-81.

11. Bønaa KH, Njølstad I, Ueland PM, et al. Homocysteine lowering and cardiovascular events after acute myocardial infarction. $N$ Engl J Med 2006;354:1578-88.

Copyright 2012 BMJ Publishing Group. All rights reserved. For permission to reuse any of this content visit http://group.bmj.com/group/rights-licensing/permissions.

BMJ Case Report Fellows may re-use this article for personal use and teaching without any further permission.

Please cite this article as follows (you will need to access the article online to obtain the date of publication).

Ukachukwu V, Idris S, Mcllwee A. Acute myocardial infarction in a young patient with hyperhomocysteinaemia. BMJ Case Reports 2012;10.1136/bcr-2012007489, Published XXX

Become a Fellow of BMJ Case Reports today and you can:

- Submit as many cases as you like

- Enjoy fast sympathetic peer review and rapid publication of accepted articles

- Access all the published articles

- Re-use any of the published material for personal use and teaching without further permission

For information on Institutional Fellowships contact consortiasales@bmjgroup.com

Visit casereports.bmj.com for more articles like this and to become a Fellow 